\title{
Posterior Subcapsular Cataract Grade 4
}

National Cancer Institute

\section{Source}

National Cancer Institute. Posterior Subcapsular Cataract Grade 4. NCI Thesaurus. Code C135204.

A stage of posterior subcapsular cataract characterized by greater than $50 \%$ of the posterior capsule obscured by opacity. (Modified LOCS II) 